\title{
Economic evaluation of cholesterol-related interventions in general practice. An appraisal of the evidence
} Trudy van der Weijden, J André Knottnerus, André J H A Ament, Henri E J H Stoffers,
Richard P T M Grol
Department of General Practice, Maastricht University, the Netherlands $T$ van der Weijden J A Knottnerus

H E J H Stoffers

Department of Health Organization Policy and Economics, Maastricht University, the Netherlands A J H A Ament

Centre for Quality of Care Research, Universities of Maastricht and Nijmegen, the Netherlands R P T M Grol

Correspondence to: Dr T van der Weijden, Department of Genera Practice, Maastricht University, PO Box 616, $6200 \mathrm{MD}$ Maastricht, the Netherlands.

Accepted for publication 28 July 1997

\begin{abstract}
Study objective-To investigate and evaluate published data on cost effectiveness of cholesterol lowering interventions, and how this information could be interpreted in a rational approach of cholesterol management in general practice.

Design-A systematic review of the literature.

Setting-No restriction on setting.

Materials-Papers reporting on the cost effectiveness or cost utility of prevention of (recurrent) coronary heart disease by reduction of hypercholesterolaemia in adults.

Main results-Thirty nine studies, most cost effectiveness analyses, were included. In 24 studies drug interventions only were analysed. Costs of screening to target cholesterol lowering interventions to persons with hypercholesterolaemia were considered in nine studies. Adjustments of the efficacy of the intervention for community effectiveness were described in seven studies. In four studies life years gained were adjusted for quality of life. Despite large variation in the outcomes, there is a constant tendency towards a less favourable cost effectiveness ratio for intervening in persons without coronary heart disease compared with persons with coro-
\end{abstract}

nary heart disease and for women compared with men.

Conclusions-There is lack of data on cost effectiveness of cholesterol lowering interventions in the general practice setting. The cost effectiveness of cholesterol lowering in general practice deteriorates when all relevant costs are taken into account and when efficacy is corrected for community effectivenes. Cholesterol lowering intervention is more cost effective in men compared with women and in patients with coronary heart disease compared with persons without coronary heart disease. Considerations from cost effectiveness analyses should be incorporated into the development and implementation of national cholesterol guidelines for general practitioners. Standardisation of cost effectiveness studies is important for future economic evaluations.

(f Epidemiol Community Health 1998;52:586-594)

Controversy surrounds the benefit of cholesterol lowering intervention to prevent coronary heart disease (CHD) in general practice patients. Internationally published guidelines on this topic differ in their restrictiveness of cholesterol screening, although they are based on the same type of evidence. The source of the

Table 1 Model for economic evaluation of cholesterol related interventions

Net health care costs:

Direct medical costs:

the screening strategy: the selection of the part of the population that has to be screened as well as the frequency of screening

the diagnostic strategy: the number of tests, the sequency of testing, further diagnostic testing following different results of the screening test, outpatient consultations or primary care consultations the therapeutic strategy:

diet therapy: education leaflets, guidance and monitoring by physician or dietitian

drug therapy: doses, frequency, number of medication days, guidance and monitoring by physician

side effects of cholesterol lowering therapy: costs of screening for and treatment of side effects

organisational costs: how and who, overhead costs, energy and maintenance, rent/housing

plus direct non-medical costs:

transportation to and from medical services, care provided by family and friends

plus indirect costs:

time spent by patient seeking medical services: change in productivity, time spent by family/friends

minus savings in health care costs due to prevention of disease

direct benefits: health care resource savings

indirect benefits: production gains from return to work

Net health effects:

several possible end points such as: change in serum cholesterol concentration, or the expected number of life years gained which are influenced by: screening and diagnostic accuracy

efficacy of the intervention

health provider compliance: refers to clinical process rather than clinical structure patient compliance

coverage: describes whether or not the individual makes contact with the health professional

plus adjusted for improvement/deterioration in the quality of life ${ }^{\star}$

Improvements in physical, psychological or social well being of patients or their carers, because of prevention of morbidity. Deteriorations in quality of life because of side effects of screening or treatment, loss of productive time (sick leave, occupational disability), travel and waiting time, psychic distress/inconveniences (for example, anxiety through labeling, false-positives/false-negatives, for example, change of eating habits). 
controversy does not only seem to lie in the attitude of physicians towards preventive medicine, but also in the ambiguous clinical epidemiological evidence on effectiveness of cholesterol lowering interventions. Personal norms and values probably play a major part in the interpretation and translation of evidence on effectiveness into policy. ${ }^{1}$ A rational approach is needed towards cholesterol guidelines, in which attention is given to both effectiveness and cost effectiveness of cholesterol lowering interventions. Although physicians in general hesitate in integrating cost considerations in medical decision making, ${ }^{2}$ economic evaluation might provide an answer to the question of efficiency of cholesterol lowering interventions.

The effectiveness of cholesterol lowering intervention depends firstly on its efficacy (can it work?), but finally on its community effectiveness (will it work when applied in the community?). Community effectiveness depends on the success of different steps, such as the physicians' ability to target people at high risk, the accuracy of screening, the extent to which uncertainties about the effectiveness of cholesterol lowering in untested patient groups are taken into account, or the patients' ability to maintain long term compliance. Table 1 lists possible parameters that may be considered in an economic evaluation of a cholesterol lowering intervention. ${ }^{3-8}$ The main body of cholesterol lowering interventions in the general practice population, which is predominantly healthy and non-symptomatic, consists of screening and diagnostic actions rather than therapeutic strategies. It is therefore important to count the costs of screening, diagnosis, counselling, and monitoring patients. The denominator of the cost effectiveness ratio is usually expressed in YOLS or QALYs. YOLS stands for Year Of Life Saved, the estimated average number of life years saved per subject, by implementing the intervention. QALY, which stands for Quality Adjusted Life Year, is a life year adjusted with a factor expressing the estimated quality of life for an average subject.

Cost and health implications of cholesterol lowering were already reviewed more or less systematically in four publications in which in total 10 economic evaluations were included. ${ }^{9-12}$ Cost effectiveness of cholesterol lowering treatment ranged from $<\$ 0$ to $\$ 1800000$ per year of life saved. These reviews were incomplete and did not discuss the impact of the study methods used in the studies on the interpretation of the results for general practice policy.

Shortcomings of economic evaluations ${ }^{13}$ may have considerable impact on the relevance of the results in the general practice setting. We are especially interested in the representativeness of the patient populations on which cost and effect assessments were based and the type of costs that were taken into account. Compliance towards cholesterol lowering interventions is a problem, especially in the long term, ${ }^{14}$ and may decrease effectiveness. The discontinuation rates reported in randomised controlled trials of cholesterol lowering drugs (about $30 \%)^{1516}$ are lower than the rates actually observed in the primary care setting. ${ }^{17}$ Poor adherence is common when the treatment regimen is preventive rather than curative, when patients are asymptomatic for the target disease, and when the duration of the treatment is long. ${ }^{18}$ From the primary care perspective it is important to consider that intangible costs of undesired side effects of cholesterol interventions might occur. It is the general practitioner, dealing with comparatively healthy people and having a confidential and continuous relationship with them, who will be confronted with these kind of costs.

The objective of this systematic review is to evaluate published data on cost effectiveness of cholesterol lowering interventions, and to interpret the value of this information in the context of a rational approach of cholesterol lowering intervention in general practice.

\section{Methods}

The studies in this review were English language papers, which had to fulfil three inclusion criteria: (a) the object of study was prevention of (recurrent) coronary heart disease by targeting hypercholesterolaemia in adults; (b) a full economic evaluation in the format of a cost effectiveness, cost utility, or cost-benefit analysis was carried out; (c) data on the economic evaluation of the cholesterol lowering intervention were presented

Table 2 Methodological quality of the economic evaluations. Criteria for assessment of the methodological quality and the number of studies that fulfilled the criteria. Total number of studies is 39

\begin{tabular}{|c|c|}
\hline Criteria for assessment of the methodological quality & Number of studies \\
\hline 1 the (alternative) intervention(s) to be analysed to (who, what, where, why, when, and how) was/were precisely described & 31 \\
\hline $\begin{array}{l}2 \text { the perspective/viewpoint for the analysis was provided (society, insurers, health care system, hospitals, physicians, patients) was explicitely } \\
\text { stated }\end{array}$ & 10 \\
\hline 3 reasonable alternative clinical interventions were being considered & 23 \\
\hline $\begin{array}{l}4 \text { the study sample, for which cost and outcome projections were made, could be judged on representativeness (experimental data, and/or } \\
\text { observational data) }\end{array}$ & 35 \\
\hline 5 the types of costs that were used or considered in the analysis were explicitely defined & 38 \\
\hline 6 average and marginal costs were differentiated & 12 \\
\hline 7 quantities of resources were reported separately from the prices (unit costs) of those resources & 29 \\
\hline 8 an explicit description of the health effects (the primary outcome measure) of the intervention being studied was provided & 36 \\
\hline 9 health effects were based on community effectiveness data & 7 \\
\hline 10 if health effects have been valued details were given of the method used & 1 \\
\hline 11 a summary measurement of efficiency, such as a cost-effectiveness ratio, was calculated & 39 \\
\hline 12 an incremental analysis was reported, comparing the relevant alternatives & 12 \\
\hline $\begin{array}{l}13 \text { adjustments made for time (that is, inflation, are future costs and benefits discounted) were reported in detail (the discount rate should be } \\
\text { given) }\end{array}$ & 28 \\
\hline $\begin{array}{l}14 \text { potential effects of important assumptions on results were measured in a sensitivity analysis by varying uncertain parameters and } \\
\text { recomputing costs and effects }\end{array}$ & 25 \\
\hline
\end{tabular}


Table 3 Characteristics of the 24 studies with drug interventions only. (YOLS = year of life saved)

\begin{tabular}{|c|c|c|c|c|}
\hline \multirow[b]{2}{*}{ Study } & \multirow{2}{*}{$\begin{array}{l}\text { Population (sex, } \\
\text { age, cholesterol, } \\
\text { CHD) }\end{array}$} & \multirow[b]{2}{*}{ Intervention } & \multirow[b]{2}{*}{ Alternative intervention } & Cost identification: \\
\hline & & & & Direct medical costs/savings \\
\hline \multicolumn{5}{|c|}{ Outcome expressed in change in cholesterol concentration } \\
\hline Schulman $1990^{72}$ & $?$ & $\begin{array}{l}\text { various, applying RCT } \\
\text { model }\end{array}$ & $\begin{array}{l}\text { various, primary care } \\
\text { model }\end{array}$ & $\begin{array}{l}\text { drug costs, monitoring costs, screening side effects, treating side } \\
\text { effects, savings in CHD care }\end{array}$ \\
\hline $\operatorname{Lim} 1992^{73}$ & $\begin{array}{l}\mathrm{M}+\mathrm{F} \\
\text { cholesterol }>6.2\end{array}$ & simvastatin & gemfibrozil & drug costs \\
\hline Blum $1994^{74}$ & ? & lova, simva, prava, fluvastatin & - & drug costs \\
\hline Smart $1994^{75}$ & ? & simvastatin & pravastatin & drug costs, monitoring costs \\
\hline Schrott $1995^{76}$ & $\begin{array}{l}\mathrm{M}+\mathrm{F} \\
\text { cholesterol ? }\end{array}$ & colestipol lovastatin & placebo & drug costs \\
\hline Oster $1996^{77} 78$ & $\begin{array}{l}\mathrm{M}+\mathrm{F} 20-70 \\
\text { cholesterol ? } \\
10 \% \mathrm{CHD}\end{array}$ & lovastatin & various stepped care & drug costs, monitoring costs, screening side effects \\
\hline \multicolumn{5}{|c|}{ Outcome expressed in morbidity/mortality } \\
\hline $\begin{array}{l}\text { Himmelstein } \\
1984^{79}\end{array}$ & $\begin{array}{l}\text { M, 35-74, } \\
\text { cholesterol }>6.7 \\
\text { CHD - }\end{array}$ & cholestyramine & free care & drug costs, savings in CHD care \\
\hline Weinstein $1985^{80} 81$ & $\begin{array}{l}\text { M } 45-50 \\
\text { cholesterol > } 6.7 \\
\text { CHD - }\end{array}$ & cholestyramine & - & drug costs, savings in CHD care \\
\hline Oster $1987^{82}$ & $\begin{array}{l}\text { M } 35-74 \\
\text { cholesterol }>6.7 \\
\text { CHD ? }\end{array}$ & drug therapy & - & $\begin{array}{l}\text { drug costs, monitoring costs, treating side effects, savings in CHD } \\
\text { care }\end{array}$ \\
\hline Kinosian $1988^{83}$ & $\begin{array}{l}\text { M } \\
\text { cholesterol }>6.9 \\
\text { CHD? }\end{array}$ & cholestyramine & colestipol oat bran & drug costs, monitoring costs, savings in CHD care \\
\hline Martens $1990^{8485}$ & $\begin{array}{l}\mathrm{M}+\mathrm{F} 35-74 \\
\text { cholesterol }>7.5 \\
\mathrm{CHD}-\end{array}$ & simvastatin & cholestyramine & drug costs, monitoring costs, savings in $\mathrm{CHD}$ care \\
\hline Sarma $1990^{86}$ & $\begin{array}{l}\text { M } 40-57 \\
\text { cholesterol }>5.2 \\
\text { CHD - }\end{array}$ & gemfibrozil & - & $\begin{array}{l}\text { drug costs, monitoring costs, screening side, effects savings in } \\
\text { CHD care }\end{array}$ \\
\hline Hay $1991^{87}$ & $\begin{array}{l}\mathrm{M}+\mathrm{F} 35-55 \\
\text { cholesterol ? } \\
\mathrm{CHD}-\end{array}$ & lovastatin & - & $\begin{array}{l}\text { drug costs, monitoring costs, screening side effects, treating side } \\
\text { effects, savings in CHD care }\end{array}$ \\
\hline Goldman $1991^{88}$ & $\begin{array}{l}\mathrm{M}+\mathrm{F} 35-84 \\
\text { cholesterol ? } \\
\mathrm{CHD}+/-\end{array}$ & lovastatin $20 \mathrm{mg}$ & lovastatin $40 \mathrm{mg}$ & $\begin{array}{l}\text { drug costs, monitoring costs, screening side effects, savings in } \\
\text { CHD care }\end{array}$ \\
\hline Glick $1992^{89}$ & $\begin{array}{l}\text { M } 50 \\
\text { cholesterol > } 7.5 \\
\text { CHD - }\end{array}$ & simvastatin & cholestyramine & drug costs, savings in CHD care \\
\hline Hjalte $1992^{90}$ & $\begin{array}{l}\text { M 37-64 } \\
\text { cholesterol >6.2 } \\
\text { CHD - }\end{array}$ & simvastatin cholestyramine & usual care & drug costs, monitoring costs, savings in CHD care \\
\hline Guibert $1993^{91}$ & ? & $\begin{array}{l}\text { lovastatin gemfibrozil } \\
\text { cholestyramine }\end{array}$ & - & drug costs, monitoring costs, savings in CHD care \\
\hline Goldman $1993^{92}$ & $\begin{array}{l}M+F \text { 35-84 } \\
\text { cholesterol } \\
>15.5 \\
\text { CHD - }\end{array}$ & lovastatin $20 \mathrm{mg}$ & lovastatin $40 / 80 \mathrm{mg}$ & drug costs, monitoring costs, savings in $\mathrm{CHD}$ care \\
\hline Martens $1994^{93}$ & $\begin{array}{l}\text { M } 45 \\
\mathrm{LDL}=4.5 \\
\mathrm{CHD}-\end{array}$ & fluva, lova, prava, simvastatin & $\begin{array}{l}\text { no drug, fluvastatin } \\
40 \mathrm{mg}\end{array}$ & drug costs, monitoring costs, savings in CHD care \\
\hline Hamilton $1995^{94}$ & $\begin{array}{l}\text { M+F } 30-70 \\
\text { cholesterol } 10^{\text {th }} \\
\text { perc } \\
\text { CHD - }\end{array}$ & $\begin{array}{l}\text { lovastatin for high risk } \\
\text { persons }\end{array}$ & $\begin{array}{l}\text { lovastatin for low risk } \\
\text { persons }\end{array}$ & $\begin{array}{l}\text { drug costs, monitoring costs, screening side effects, savings in } \\
\text { CHD care }\end{array}$ \\
\hline Pharaoh $1996^{95}$ & $\begin{array}{l}\text { M+F 45-64 } \\
\text { cholesterol } \\
>5.5 / 6.6 \\
\text { CHD +/- }\end{array}$ & statin & - & drug costs, savings in CHD care \\
\hline Ashraf $1996^{96}$ & $\begin{array}{l}\mathrm{M} \\
\text { cholesterol ? } \\
\mathrm{CHD}+\end{array}$ & pravastatin & usual care & $\begin{array}{l}\text { drug costs, monitoring costs, screening side effects, savings in } \\
\text { CHD care }\end{array}$ \\
\hline Jönsson $1996^{97}$ & $\begin{array}{l}\mathrm{M}+\mathrm{F} \\
\text { cholesterol } \\
5.5-8.0 \\
\mathrm{CHD}+\end{array}$ & simvastatin & placebo & drug costs, savings in CHD care \\
\hline $\begin{array}{c}\text { Johannesson } \\
1997^{98}\end{array}$ & $\begin{array}{l}\mathrm{M}+\mathrm{F} 35-70 \\
\text { cholesterol } \\
5.5-8.0 \\
\mathrm{CHD}+\end{array}$ & simvastatin & placebo & drug costs, savings in CHD care \\
\hline
\end{tabular}


separately from any other coronary heart disease related intervention.

Four search strategies were executed to

\begin{tabular}{|c|c|c|}
\hline Other costs/savings & Score & $C E$ ratio (price tariff date) \\
\hline- & 12 & $\begin{array}{l}\$ 139-347 \text { per } 5 \text { y } \\
\% \text { cholesterol } \downarrow \\
(1989)^{\star}\end{array}$ \\
\hline- & 7 & $\begin{array}{l}\text { \$54-64 per month } \\
\text { mmol/1 } \downarrow \text { LDL } \\
\text { (?) }\end{array}$ \\
\hline- & 4 & $\begin{array}{l}\$ 15-52 \text { per year } \\
\% \text { cholesterol } \downarrow \\
\text { (?) }\end{array}$ \\
\hline- & 8 & $\begin{array}{l}\text { R6785-8674 } \\
\text { patient reaching target level } \\
\text { (1994) }\end{array}$ \\
\hline- & 7 & $\begin{array}{l}\$ 21-28 \text { per year } \\
\% \text { cholesterol } \downarrow \\
\text { (?) }\end{array}$ \\
\hline- & 8 & $\begin{array}{l}\$ 41-49 \text { per year } \\
\% \text { cholesterol } \downarrow \\
\text { (1992) }\end{array}$ \\
\hline- & 6 & $\begin{array}{l}\$ 775600 \\
\text { per averted MI } \\
\text { (?) }\end{array}$ \\
\hline- & 6 & $\begin{array}{l}\$ 126000 \\
\text { YOLS } \\
\text { (?) }\end{array}$ \\
\hline- & 10 & $\begin{array}{l}\$ 36000-1 \text { million } \\
\text { YOLS } \\
(1985)^{\star}\end{array}$ \\
\hline unemployment savings & 11 & $\begin{array}{l}\$ 17800-117400 \\
\text { YOLS } \\
(?)^{\star}\end{array}$ \\
\hline- & 9 & $\begin{array}{l}\text { M: F46-100000 } \\
\text { YOLS } \\
\text { F: F128-162000 } \\
\text { YOLS } \\
\text { (?) }\end{array}$ \\
\hline- & 6 & $\begin{array}{l}-\$ 17800 \\
\text { per averted MI } \\
\text { (?) }\end{array}$ \\
\hline- & 9 & $\begin{array}{l}\$ 9000-297000 \\
\text { YOLS } \\
\text { (?) }\end{array}$ \\
\hline- & 10 & $\begin{array}{l}\text { CHD-: } \$ 13000-330000 \\
\text { YOLS } \\
\text { CHD+: } \$ 0-19000 \\
\text { YOLS } \\
(1989)\end{array}$ \\
\hline- & 7 & $\begin{array}{l}\text { f9600-36 } 000 \\
\text { YOLS } \\
\text { (1989) }\end{array}$ \\
\hline- & 8 & $\begin{array}{l}\text { SEK } 149400-1175 \text { million } \\
\text { YOLS } \\
\text { (1988) }\end{array}$ \\
\hline- & 7 & $\begin{array}{l}\text { Can } \$ 34 \text { 687-0.4 million } \\
\text { YOLS } \\
(1991)\end{array}$ \\
\hline- & 10 & $\begin{array}{l}\$ 0-120000 \\
\text { YOLS } \\
(1989)^{\star}\end{array}$ \\
\hline - & 11 & $\begin{array}{l}\text { Can\$38 800-56 } 200 \\
\text { YOLS } \\
(1993)^{\star}\end{array}$ \\
\hline- & 10 & $\begin{array}{l}\text { M: \$20 882-76749 } \\
\text { YOLS } \\
\text { F: } 36627-155891 \\
\text { YOLS } \\
(1992 / 93)\end{array}$ \\
\hline- & 8 & $\begin{array}{l}\text { CHD-: } £ 420-1.4 \text { million } \\
\text { YOLS } \\
\text { CHD+: } £ 6-143000 \\
\text { YOLS } \\
\text { (?) }\end{array}$ \\
\hline- & 11 & $\begin{array}{l}\$ 7124-12655 \\
\text { YOLS } \\
(1995)^{\star}\end{array}$ \\
\hline- & 8 & $\begin{array}{l}£ 5502 \\
\text { YOLS } \\
(1995)\end{array}$ \\
\hline unemployment savings & 10 & $\begin{array}{l}\text { M: } \$<0-6200 \\
\text { YOLS } \\
\text { F: }<0-13300 \\
\text { YOLS } \\
\text { (1995) }\end{array}$ \\
\hline
\end{tabular}
locate relevant studies: (a) Medline 19661996, in which thesaurus and free text keywords were combined; (b) National Health Service Centre for Reviews and Dissemination Economic Evaluations Database, University of York (internet address: nhscrd.york.ac.uk); (c) bibliography of health care cost-benefit and cost effectiveness evaluations 1979-1990 ${ }^{19}$; (d) snowballing. The following keywords were used in the Medline search: thesaurus; hypercholesterolemia/economics, (hypercholesterolemia/all subheadings and cost-benefit analysis/ all subheadings), explode anticholesteremicagents/economics; freetext; ((economic evaluation or cost effectiveness analysis) and (cholesterol or hypercholesterole?mia) in title)).

A standardised form was used to extract data from the studies. Table 2 lists the criteria for assessment of methods and parameters used in the economic evaluation. ${ }^{20-24}$ Because of the heterogeneity in the methods of measuring as well as in the type of costs and outcomes, it was impossible to summarise the results by means of statistical pooling techniques.

\section{Results}

Twenty papers were excluded from this review after careful consideration. In one study the cholesterol related intervention was targeted at children instead of adults, ${ }^{25}$ two studies were cost minimisation analyses, ${ }^{26}{ }^{27}$ six studies were partial instead of full economic evaluations, for example, calculation of costs only, ${ }^{28-33}$ in seven studies the results on cholesterol lowering interventions could not be separated from the combined interventions that were the subject of study. ${ }^{34-40}$ Two studies simulated a full cost effectiveness analysis using hypothetical data only ${ }^{4142}$ Double publication occurred twice. ${ }^{434}$

Thirty nine studies fulfilled the inclusion criteria. Most of these studies $(n=34)$ were published recently, in the nineties. Four of the studies were cost utility analyses with Quality Adjusted Life Years in the denominator of the cost-effectiveness ratio. The other 35 included studies were cost effectiveness analyses. The timespan of the evaluation ranged from four months to lifetime intervention.

Table 2 shows the results on the methodological criteria at group level. (Full tables with general and economic characteristics of the individual studies can be requested from the first author.) The perspective of the analysis was explicitely stated in 10 studies, with a societal perspective in nine studies, and the patient's perspective in one. The most reasonable alternative interventions were being studied in 23 studies, whereas no alternative intervention at all was being considered in 13 studies. Data on effectiveness of the intervention were based on published randomised controlled trials in 31 studies. Observational data were also used in the calculations of effects in 26 studies, which was the Framingham Heart Study in 19 of these cases. Health effects were seldomly based on community effectiveness data; screening and diagnostic accuracy 
Table 4 Characteristics of the 15 studies with interventions that were not limited to drug interventions. (YOLS = year of life saved, $Q A L Y=q u a l i t y$ adjusted life year)

\begin{tabular}{|c|c|c|c|c|}
\hline \multirow[b]{2}{*}{ Study } & \multirow{2}{*}{$\begin{array}{l}\text { Population (sex, age, } \\
\text { cholesterol, CHD) }\end{array}$} & \multirow[b]{2}{*}{ Intervention } & \multirow[b]{2}{*}{ Alternative intervention } & \multirow{2}{*}{$\begin{array}{l}\text { Cost identification: } \\
\text { Direct medical costs/savings }\end{array}$} \\
\hline & & & & \\
\hline \multicolumn{5}{|c|}{ Outcome expressed in change in cholesterol concentration } \\
\hline Oster $1986^{99}$ & $\begin{array}{l}\mathrm{M} \\
\text { cholesterol }>6.7\end{array}$ & cholesterol lowering & - & savings in $\mathrm{CHD}$ care \\
\hline Wilson $1992^{100}$ & factory employees & screening + diet therapy ( + incentive) & screening & $\begin{array}{l}\text { screening costs, diet therapy costs, } \\
\text { administration costs }\end{array}$ \\
\hline Tomson $1995^{101}$ & $\begin{array}{l}\mathrm{M}+\mathrm{F} 25-54 \\
\text { cholesterol } 7.0-7.8 \\
\mathrm{CHD}-\end{array}$ & intense diet therapy & diet therapy & diet therapy costs, monitoring costs \\
\hline McGehee $1995^{102}$ & $\begin{array}{l}\mathrm{M}+\mathrm{F} 20-80 \\
\text { cholesterol? }\end{array}$ & diet therapy & - & diet therapy costs \\
\hline \multicolumn{5}{|c|}{ Outcome expressed in morbidity/mortality } \\
\hline Kelley $1990^{103}$ & $\begin{array}{l}\text { M } 40 \\
\text { cholesterol }>6.9 \\
\text { CHD? }\end{array}$ & diet therapy, various drugs & - & $\begin{array}{l}\text { diet therapy costs, drug costs, treating side } \\
\text { effects, savings in CHD care }\end{array}$ \\
\hline Reckless $1990^{104}$ & $\begin{array}{l}\mathrm{M}+\mathrm{F} \text { 20-65 } \\
\text { cholesterol? } \\
\mathrm{CHD} ?\end{array}$ & screening + diet therapy $(+$ drug therapy) & - & $\begin{array}{l}\text { screening costs, diet therapy costs, drug } \\
\text { costs, monitoring costs, savings in CHD } \\
\text { care }\end{array}$ \\
\hline Med Adv C. ' $90^{105}$ & $\begin{array}{l}\mathrm{M}+\mathrm{F} 25-69 \\
\text { cholesterol ? } \\
\mathrm{CHD} \text { ? }\end{array}$ & screening + diet therapy $(+$ drug therapy) & - & $\begin{array}{l}\text { screening costs, diet therapy costs, drug } \\
\text { costs, monitoring costs, savings in CHD } \\
\text { care }\end{array}$ \\
\hline Assmann $1990^{106}$ & $\begin{array}{l}\mathrm{M}+\mathrm{F} \text { ? } \\
\text { cholesterol ? } \\
\mathrm{CHD}-\end{array}$ & West Germany guidelines & - & $\begin{array}{l}\text { diet therapy costs, drug costs, monitoring } \\
\text { costs, savings in CHD care }\end{array}$ \\
\hline Kristiansen $1991^{107}$ & $\begin{array}{l}\text { M } 40-49 \\
\text { cholesterol ? } \\
\text { CHD? }\end{array}$ & health promotion, diet (+ drugs) & no care & $\begin{array}{l}\text { health promotion costs, screening costs, } \\
\text { drug costs, monitoring costs, screening } \\
\text { side effects, savings in CHD care }\end{array}$ \\
\hline Weissfeld $1992^{108109}$ & $\begin{array}{l}\text { M 50-60 } \\
\text { cholesterol ? } \\
\text { CHD? }\end{array}$ & NCEP guidelines & no care & $\begin{array}{l}\text { screening costs, diet therapy costs, drug } \\
\text { costs, monitoring costs, screening side } \\
\text { effects, savings in CHD care }\end{array}$ \\
\hline Kinlay $1994^{110}$ & $\begin{array}{l}\text { M, 35-64 } \\
\text { cholesterol ? } \\
\text { CHD? }\end{array}$ & screening + diet therapy $(+$ cholestyramine $)$ & - & $\begin{array}{l}\text { screening costs, diet therapy costs, drug } \\
\text { costs, monitoring costs, savings in CHD } \\
\text { care }(>80 \% \text { of the costs were for drugs })\end{array}$ \\
\hline Field $1995^{111}$ & $\begin{array}{l}\mathrm{M}+\mathrm{F} 35-64 \\
\text { cholesterol ? } \\
\mathrm{CHD} ?\end{array}$ & screening high risk patients & screening all patients & $\begin{array}{l}\text { screening costs, counselling costs, costs of } \\
\text { therapy, monitoring costs, savings in } \\
\text { CHD care }\end{array}$ \\
\hline Johannesson $1996^{112}$ & $\begin{array}{l}\text { M } 30-59 \\
\text { cholesterol? } \\
\text { CHD - }\end{array}$ & usual advice + drugs intensive advice (+ drugs) & usual advice & $\begin{array}{l}\text { counselling costs, diet therapy costs, drug } \\
\text { costs, monitoring costs, savings in CHD } \\
\text { care }\end{array}$ \\
\hline Stinnett $1996^{113}$ & $\begin{array}{l}\mathrm{M}+\mathrm{F} 35-84 \\
\mathrm{LDL}>4.1 \\
\mathrm{CHD}+/-\end{array}$ & diet therapy (+ niacin) (+ lovastatin) & no care & $\begin{array}{l}\text { screening costs, diet therapy costs, drug } \\
\text { costs, monitoring costs, savings in CHD } \\
\text { care non-CHD care costs }\end{array}$ \\
\hline Plans $1997^{114}$ & $\begin{array}{l}\text { M+F 35-69 } \\
\text { cholesterol 5.7-9.8 } \\
\text { CHD? }\end{array}$ & high risk diet therapy & $\begin{array}{l}\text { population diet } \\
\text { approach }\end{array}$ & $\begin{array}{l}\text { screening costs, diet therapy costs, } \\
\text { monitoring costs, savings in CHD care }\end{array}$ \\
\hline
\end{tabular}

${ }^{\star}$ Incremental cost effectiveness ratio.

was accounted for in one study only. ${ }^{108} 109$ Adjustments of the effectiveness of the intervention for patient compliance was described in six studies. ${ }^{77} 78100102110113114$ In 23 of 28 studies in which the discount rate was given it was $5 \%$.

In nearly two third of the studies $(n=24)$ drug interventions only were considered for the analysis. Table 3 gives some relevant characteristics of these studies. In six studies the clinical outcome was expressed as the change in cholesterol concentration. In the other 18 studies the denominator of the CE ratio was Year Of Live Saved or averted myocardial infarction (twice). Drug therapy related costs were limited to the costs of the drugs in nine of these 24 studies. Non-medical costs or savings were calculated in two studies, namely unemployment savings. The study populations were limited to (middle aged) men in nine studies, and were in most cases free of coronary heart disease. Most studies were based on the new generation drugs, the statins. The goal of this review was to estimate the methodological quality of the published economic evaluations and their value for general practice policy, not to arrive at an average cost effective ratio. The cost effective ratios are reported in table 3 to show the wide variation in the CE ratios in and between studies, and general trends in cost effectiveness. The comparibility of the cost effective ratios is low because of differences in many parameters, some of which are: differences in methodological quality, in populations studied (sex, age, presence of coronary heart disease or other cardiovascular risk factors, baseline cholesterol level), in types and intensities of intervention, in the assessment of the net health effect of the intervention, which depends on the quality of the underlying 
Table 4 (Continued)

\begin{tabular}{|c|c|c|}
\hline Other costs/savings & Score & CE ratio (price tariff value) \\
\hline unemployment savings & 6 & $\begin{array}{l}\$ 1-16000 \\
15 \% \text { cholesterol } \downarrow \\
(1980)\end{array}$ \\
\hline - & 9 & $\begin{array}{l}\$ 2-5 \\
\% \text { cholesterol } \downarrow \\
(1989)\end{array}$ \\
\hline patients' costs: loss of working time, transport & 7 & $\begin{array}{l}\text { SEK } 229-974 \\
\% \text { cholesterol } \downarrow \\
\text { (1993) }\end{array}$ \\
\hline - & 5 & $\begin{array}{l}\$ 19 \\
\% \text { cholesterol } \downarrow \\
\text { (?) }\end{array}$ \\
\hline unemployment savings & 4 & $\begin{array}{l}-\$ 2536-108826 \\
\text { YOLS } \\
(1987)\end{array}$ \\
\hline - & 7 & $\begin{array}{l}£ 550 \\
\text { QALY } \\
(1989)\end{array}$ \\
\hline - & 7 & $\begin{array}{l}\text { £2852 } \\
\text { QALY } \\
(?)^{\star}\end{array}$ \\
\hline- & 6 & $\begin{array}{l}\text { M: DM30-40 } 000 \\
\text { YOLS } \\
\text { F: DM86-110000 } \\
\text { YOLS }\end{array}$ \\
\hline - & 9 & $\begin{array}{l}\text { health promotion: } £ 10 \\
\text { QALY } \\
\text { diet: } £_{100} 546 \\
\text { QALY } \\
\text { diet+drugs: } £ 125860 \\
\text { QALY } \\
(1990)\end{array}$ \\
\hline - & 9 & $\begin{array}{l}\text { \$12 761-22553 } \\
\text { YOLS } \\
(1989)^{\star}\end{array}$ \\
\hline - & 9 & $\begin{array}{l}\text { \$A335 825-1.5 million } \\
\text { averted CHD event } \\
(1988 / 89)\end{array}$ \\
\hline - & 11 & $\begin{array}{l}\text { M: } £ 2720 \\
\text { YOLS } \\
\text { F: } £ 5040 \\
\text { YOLS } \\
(?)^{\star}\end{array}$ \\
\hline patients' costs: loss of working time, transport & 11 & $\begin{array}{l}\$ 61000-223000 \\
\text { YOLS } \\
(1991)^{\star}\end{array}$ \\
\hline patients' costs: loss of working time, transport & 13 & $\begin{array}{l}\text { M: } \$ 917-3 \text { million } \\
\text { QALY } \\
\text { F: } \$ 908-170888 \\
\text { QALY } \\
(1993)^{\star}\end{array}$ \\
\hline - & 12 & $\begin{array}{l}\text { M: \$6270-61439 } \\
\text { YOLS } \\
\text { F: \$28 067-171459 } \\
\text { YOLS } \\
(1990)^{\star}\end{array}$ \\
\hline
\end{tabular}

evaluation studies, in the extent of costs measured, in the differences in cost calculations between health care systems/countries, in the degree of subjecting assumptions used to sensitivity analyses, in the use of average or incremental cost effectiveness ratios, or in the differences in monetary units and price tariff dates at the time of calculating the cost effective ratios. Nevertheless, there seems to be a consistent tendency towards a less favourable cost effectiveness ratio for women compared with men and for persons without coronary heart disease compared with persons with coronary heart disease.

Table 4 list the 15 studies in which interventions were not limited to drug interventions. Because most of these studies report on non-referred patients, this group of studies seems more representative for the general practice setting than the group of studies described in table 3. In the study of Oster published in 1986 calculations were made with Framingham data for people with different concentrations of serum cholesterol to assess the cost effectiveness of cholesterol lowering by whatever kind of intervention. ${ }^{99}$ Nearly all $(\mathrm{n}=$ 12) studies considered diet therapy in the calculations. Costs of screening to target the cholesterol lowering interventions to persons with hypercholesterolaemia were considered in nine studies. All four cost utility analyses fell in this group of studies. Only in some of the cost utility analyses were intangible costs, for example, the loss of quality in life because of diet therapy, discussed. Again, wide variation is seen in the cost effective ratios, ranging from reasonable to low cost effectiveness, as well as the same tendencies considering sex and persons with or without coronary heat disease.

\section{Discussion}

Most economic evaluations of cholesterol lowering interventions focus on certain drugs, with cost calculations limited to direct drug related costs. Little is known about cost effectiveness of cholesterol lowering interventions including screening and diagnostic costs of targeting the persons with hypercholesterolaemia, which is an important part of risk management in general practice. Patient compliance, indirect nonmedical costs, and intangible costs were hardly or not taken into account in the economic evaluations. Both the variation in parameters that were used in the economic models as well as the variation in methodological quality in the studies is striking. Cost effectiveness of cholesterol lowering drug therapy in patients without coronary heart disease was highly variable depending on age and risk and generally unfavourable, and seems less favourable if indirect patient related costs are taken into account. Despite the large variation in the cost effectiveness ratios in and between the studies, there is a consistent tendency towards a less favourable cost effectiveness ratio for women compared with men and for persons without coronary heart disease compared with persons with coronary heart disease.

Some assumptions used in many of these studies need attention. It was often assumed that lowering a person's cholesterol concentration would change his or her risk profile in the direction of the risk of a person whose cholesterol concentration had never been increased. With the exception for one study, ${ }^{113}$ it was also assumed that there will be no side effects from cholesterol reduction, and that there will be no changes in the rates of non-coronary morbidity in persons whose cholesterol concentration was reduced. ${ }^{9}$ Another assumption was that overall mortality decreases, which was only recently confirmed in two statin trials. ${ }^{16}{ }^{45}$ The analyses by Pharoah, Jönsson and Johannsson deserve special attention as they were based on data from these trials; cost effectiveness ratios were in general unfavourable for the subgroup of persons without coronary heart disease despite the fact that only drug costs were considered. Another assumption applicated in most studies is the correct classification of people with 
respect to the serum cholesterol concentration. Measurement error in the determination of lipid concentrations changes the effectiveness of cholesterol interventions, ${ }^{46}{ }^{47}$ it worsens the cost effectiveness ratios of case finding and treatment programmes by $11-12 \%{ }^{48}$ or even by 17 to $29 \%{ }^{49}$

There are specific limitations of the economic evaluations from the viewpoint of the primary care field. Costs of targeting persons with hypercholesterolaemia were not calculated in 30 of 39 studies. This is reasonable in the three studies restricted to patients with pre-existing coronary heart disease, because the cholesterol lowering treatment will simply be added to standard treatment and will incur few additional costs associated with doctor time. But, in asymptomatic people, there would be additional costs associated with cholesterol testing in a healthy population, and increased use of doctor time in those subsequently treated. A restrictive screening policy already increases workload considerably, ${ }^{50-52}$ which can lead to considerable costs. ${ }^{28} 3032$

Another limitation is that intangible costs were hardly discussed in the studies. Even small disutilities associated with screening and treatment seem to be able to outweigh the benefits of aggressive cholesterol lowering strategies..$^{53}$ Diet therapy, for example, seemed cost effective per YOLS but far less favourable per QALY. In Stinnett's study it was assumed that diet and medication do not affect patients' health related quality of life. Although it is not always confirmed, ${ }^{54}$ patients may exhibit adverse psychological response to being labelled with the diagnosis of hypercholesterolaemia. Failure to acknowledge some of the specific complexities of hypercholesterolaemia (for example natural fluctuations in serum cholesterol concentrations, variability of response to diet) may result in considerable anxiety. ${ }^{56}$ Healthy (asymptomatic) persons diagnosed as hypertensive patients are at increased risk of work absenteeism and other behavioural changes. ${ }^{57}{ }^{58} \mathrm{An}$ increase in work absenteeism could not be found in persons that were positively screened for hypercholesterolaemia. ${ }^{59}$ But, higher scores on anxiety and lower scores on mood were reported, three months to a year after cholesterol screening. ${ }^{60-62}$ Especially the elderly seem at risk for labelling effects because they have a somewhat higher serum cholesterol. ${ }^{63}$

The reverse of labelling is the feeling of invulnerability after detection of a "normal serum cholesterol concentration" (a certificate of health) or the start of cholesterol lowering drug therapy (the magic bullets). It may encourage unhealthy behaviour in people at high risk. ${ }^{64}$ People with normal cholesterolaemic concentrations may not improve their lifestyle as much, ${ }^{64} 65$ or might even deteriorate their lifestyle compared with positively screened persons. ${ }^{66}$ False-negative results may produce the false sense of security, resulting in delays in seeking medical care when warning symptoms become present. ${ }^{67}$ Screening programmes affect a large number of people relative to the number who benefit. A small adverse

\section{KEY POINTS}

- Little is known about cost effectiveness of cholesterol lowering interventions including screening and diagnostic costs of targeting asymptomatic persons with hypercholesterolaemia.

- Incorporation of the disutility of screening and treatment of healthy persons with hypercholesterolaemia may result in less interventionist policies.

- Considerations on cost efectiveness should be incorporated into the development of cholesterol guidelines for general practioners.

effect of screening on quality of life, health promoting behaviour, or individuals' capacity to care for themselves could have an impact on the public health that outweighs any health gain to be achieved by screening. ${ }^{68}$

Thus, the efficiency of cholesterol lowering interventions might be reduced when some of the assumptions used in the economic evaluations are critically evaluated, when screening and diagnostic costs are calculated for cholesterol lowering interventions in persons without coronary heart disease, when adjustments are made for patient compliance, and when intangible costs are considered. Incorporation of the disutility of screening and treatment may result in less interventionist and less costly policies. On the other hand, costs of screening (targeting symptomless persons with hypercholesterolaemia) can be much lower if guidelines are simplified $^{29}$ and accuracy of classification is improved. ${ }^{69}$

We conclude that the methodological quality of the published economic evaluations is disappointing in several aspects, with specific limitations from the viewpoint of the primary care field. Although no robust conclusions can be drawn about the cost effectiveness of cholesterol lowering interventions in general practice at this time, cholesterol lowering tends to be more cost effective in patients with coronary heart disease than in persons not known to have coronary heart disease and in men compared with women. Considerations from cost effectiveness analyses should be incorporated into the development and implementation of future national cholesterol guidelines. The need for standardisation of these kind of studies is obvious. ${ }^{70}$ Recently published guidelines for standardisation should have impact on future economic evaluations, ${ }^{82471}$ to build decisions about practice guidelines on a balance of rationality on the one hand and individual norms and values on the other.

Funding: this research was supported by a grant from the Dutch Heart Foundation.

Conflicts of interest: none.

1 Davidoff F. Evangelists and snails redux: the case of cholesterol screening. Ann Intern Med 1996;124:513-14.

2 Detsky AS, Naglie IG. A clinician's guide to costeffectiveness analysis. Ann Intern Med 1990;113:147-54.

3 Tugwell P, Bennett KJ, Sackett DL, Haynes RB. The measurement iterative loop: A framework for the critical appraisal of need, benefits and costs of health interventions. fChron Dis 1985;38:339-51. 
4 Drummond MF, Stoddart GL, Torrance GW. Methods for the economic evaluation of health care programmes. Oxford: Press, 1987.

5 O'Brien B, Rushby J. Outcome assessment in cardiovascular cost-benefit studies. Am Heart f 1990;119:740-8.

6 Maynard A. The design of future cost-benefit studies. $A m$ Heart f 1990;119:761-5.

7 Luce BR, Elixhauser A. Estimating costs in the economic evaluation of medical technologies. Int $\mathcal{f}$ Technol Assess Health Care 1990;6:57-75.

8 Weinstein MC, Siegel JE, Gold MR, Kamlet MS, Russell $\mathrm{LB}$, for the Panel on Cost-Effectiveness in Health and Medicine. Recommendations of the Panel on CostEffectiveness in Health and Medicine. $7 A M A$ 1996;276: Effectiven

9 Goldman L, Gordon DJ, Rifkind BM, et al. Cost and health implications of cholesterol lowering. Circulation 1992;85: 1960-8

10 Kupersmith J, Holmes-Rovner M, Hogan A, Rovner D, Gardiner J. Cost-effectiveness analysis in heart disease,
Part II: Preventive therapies. Progr Cardiovasc Dis 1995;37: 243-71.

11 Chrisp P. Simvastatin in hypercholesterolaemia. Pharmacoeconomics $1992 ; 1: 124-45$.

12 Tengs TO, Adams ME, Pliskin JS, et al. Five-hundred life-saving interventions and their cost-effectiveness. Risk Analysis 1995;15:369-90.

13 Baltussen R, Ament A, Leidl R. Making cost assessments based on RCTs more useful to decision-makers. Health based on RCTs more
Policy 1996;37:163-83.

14 Beurden E van, James R, Montague D, Christian J, Dunn T. Community-based cholesterol screening and education to prevent heart disease: five-year results of the North Coast Cholesterol Check Campaign. Aust $\mathcal{f}$ Public Health 1993;17:109-16.

15 Mäenpää H, Manninen V, Heinonen OP. Compliance with medication in the Helsinki Heart Study. Eur $\mathcal{f}$ Clin Pharmacol 1992;42:15-19.

16 Shepherd J, Cobbe SM, Ford I, et al for the West of Scotland Coronary Prevention Study Group. Prevention of coronary heart disease with pravastatin in men with hypercholesteroheart disease with pravastatin in men with

17 Andrade SE, Walker AM, Gottlieb LK, et al. Discontinuation of antihyperlipidemic drugs. Do rates reported in clini$\mathrm{cal}$ trials reflect rates in primary care settings? $N \mathrm{Engl} F \mathrm{Med}$ 1995;332:1125-31.

18 Rand CS. Measuring adherence with therapy for chronic diseases: implications for the treatment of heterozygous familial hypercholesterolemia. Am 7 Cardiol 1993;72:68$74 \mathrm{D}$

19 Elixhauser A, Luce BR, Taylor WR, Reblando J. Health care CBA/CEA: An update on the growth and composition of the literature. Med Care 1993;31 (suppl 31):JS1-11.

20 Shephard DS, Thompson MS. First principles of costeffectiveness analysis in health. Public Health Rep 1979;94: 535-43.

21 Guyatt G, Drummond M, Feeny D, Haynes RB, Tugwell P. Guidelines for health technology assessment: therapeutic technologies. In: Feeny D, Guyatt G, Tugwell P, eds. Health care technology. Effectiveness, efficiency and public policy. Montreal: The Institute for Research on Public Policy, 1986.

22 Udvarhelyi S, Colditz GA, Rai A, Epstein AM. Costeffectiveness and cost-benefit analyses in the medical literature. Ann Intern Med 1992;116:238-44.

23 Drummond M, Brandt A, Luce B, Rovira J. Standardizing methodologies for economic evaluation in health care. Practice, problems, and potential. Int $f$ Technol Assess Health Care 1993;9:26-36.

24 Drummond MF, Jefferson TO, the BMJ Economic Evaluation Working Party. Guidelines for authors and peer reviewers of economic submissions to the BMJ. BMf 1996; 313:275-83.

25 Berwick DM, Cretin S, Keeler E. Cholesterol, children, and heart disease: an analysis of alternatives. Pediatrics 1981;68: 721-30.

26 Korman L, Borysiuk L. Replacing lovastatin with pravastatin: effect on serum lipids and costs. Am 7 Health Syst Pharm 1995;52:1078-82.

27 Pedersen TR, Kjekshus J, Berg K, et al; for the Scandinavian Simvastatin Survival Study Group. Cholesterol lowering and the use of healthcare resources. Results of the Scandinavian Simvastatin Survival Study. Circulation 1996;93: navian Sim 17962 .

28 Johannesson $\mathrm{M}$, Borgquist L, Nilsson-Ehle P, Jönsson B, Ekbom T, Lindholm L. The cost of screening for hypercholesterolemia - Results form a clinical trial in Swedish primary health care. Scand F Clin Lab Invest 1993; 53:725-32.

29 Hofer T, Weissfeld J. Designing a simpler high blood cholesterol case detection strategy: are the advantages of the NCEP protocol worth the complexity? Med Decis Making 1994;14:357-68.

30 Garber AM, Littenberg B, Sox HC, Wagner JL, Gluck M. Costs and health consequences of cholesterol screening for asymptomatic older Americans. Arch Intern Med 1991;151: 1089-95.

31 Heudebert GR, Van Ruiswyk J, Hiatt J, Schectman G. Combination drug therapy for hypercholesterolemia. Arch Combination drug therapy for

32 Grover SA, Coupal L, Fahkry R, Suissa S. Screening for hypercholesterolemia among Canadians: How much will it cost? Can Med Assoc f 1991;144:161-8. 33 Eddy DM. Rationing resources while improving quality.

34 Bloom BS. Medical management and managing medical care: The dilemma of evaluating new technology. Am Heart f 1990:119:754-61.

35 Lindholm L, Rosén M, Weinehall L, Asplund K. Cost effectiveness and equity of a community based cardiovascular disease prevention programme in Norsjö, Sweden. $\mathcal{F}$ Epidemiol Community Health 1996;50:190-5.

36 Hall JP, Heller RF, Dobson AJ, Lloyd DM, Sanson-Fisher RW, Leeder SR. A cost-effectiveness analysis of alternative strategies for the prevention of heart disease. Med $\mathcal{F}$ Aust 1988;148:273-7.

37 Langham S, Thorogood M, Normand C, Muir J, Jones L, Fowler G. Costs and cost-effectiveness of health checks conducted by nurses in primary care: the Oxcheck study. BMf 1996;312:1265-8.

38 Wonderling D, McDermott C, Buxton M, et al. Costs and cost-effectiveness of cardiovascular screening and
intervention: the British family heart study. BMf 1996;312: 1269-73.

39 Wonderling D, Langham S, Buxton M, Normand C, McDermott C. What can be concluded from the Oxcheck and British family heart studies on cost-effectiveness analyses. BMF 1996;312:1274-8

40 O'Neill C, Normand C, Cupples M, McKnight A. Cost effectiveness of personal health education in primary care for people with angina in the Greater Belfast area of
Northern Ireland. F Epidemiol Community Health 1996;50: 538-40.

41 Yusuf S, Anand S. Cost of prevention. The case of lipid lowering. Circulation 1996;93:1774-6.

42 Drummond MF, Heyse J, Cook J, McGuire A. Selection of end points in economic evaluations of coronaryheart-disease interventions. Med Decis Making 1993;13: $184-90$

43 Hogan T. Health and economic issues in the prevention of coronary heart disease. Am f Cardiol 1995;76:140-2A.

44 Chrisp P, Lewis NJW, Milne RJ. Simvastatin: a pharmacoeconomic evaluation of its cost-effectiveness in hypercholesterolaemia and prevention of coronary heart disease. PharmacoEconomics 1992;1:124-45.

45 Scandinavian Simvastatin Survival Study Group. Randomised trial of cholesterol lowering in 4444 patients with coronary heart disease: the Scandinavian Simvastatin Survival Study. Lancet 1994;344:1383-9.

46 Strachan D, Rose G. Strategies of prevention revisited: effects of imprecise measurement of risk factors on the evaluation of "high-risk" and "population-based" approaches to prevention of cardiovascular disease. 7 Clin Epidemiol 1991;44:1187-96.

47 Forrow L, Calkins DR, Allshouse K, Horowitz G, Delbanco TL. Evaluating cholesterol screening. The importance of controlling for regression to the mean. Arch Intern Med 1995;155:2177-84.

48 Weissfeld JL, Holloway JJ. Precision of blood cholesterol measurement and high blood cholesterol case-finding and treatment. F Clin Epidemiol 1992;45:971-84

9 Martens LL. Effect of biological and analytical variation in cholesterol measurement on the cost-effectiveness of cholesterol-lowering therapy. PharmacoEconomics 1992;2: 414-21.

50 Imperial Cancer Research Fund OXCHECK Study Group. Prevalence of risk factors for heart disease in OXCHECK 1991;302:1057-60.

51 Silagy C, Mant D, Carpenter L, Muir J, Neil A. Modelling different strategies to prevent coronary heart disease in primary care. F Clin Epidemiol 1994;47:993-1001.

52 Robertson $M$. Costs in general practice. [Letter]. BMf 1996;313:1143-4.

53 Krahn M, Naylor D, Basinski AS, Detsky AS. Comparison of an aggressive (U.S.) and a less aggressive (Canadian) policy for cholesterol screening and treatment. Ann Intern Med 1991;115:248-55

54 Havas S, Reisman J, Hsu L, et al. Does cholesterol screening result in negative labeling effects? Results of the Massachusetts Model System for Blood Cholesterol Screening Project. Arch Intern Med 1991;151:113-19.

55 Christensen B. Psychological reactions to information about risk of ischaemic heart disease in

56 Brett AS. Psychologic effects of the diagnosis and treatment of hypercholesterolemia: lessons from case studies. $A m \mathcal{F}$ Med 1991;91:642-7.

57 Lefebvre RC, Hursey KG, Carleton RA. Labeling of participants in high blood pressure screening programmes. Implications for blood cholesterol screenings. Arch Intern Med 1988:148:1993-7.

58 MacDonald LA, Sackett DL, Haynes RB, et al. Labelling in hypertension: a review of the behavioral and psychological consequences. F Chron Dis 1984;37:933-42.

59 Råstam L, frick JO, Gullberg B. Work absenteeism in men who are labelled hypercholesterolaemic at screening. Eur Heart F 1991;12:1316-20.

60 Stoate HG. Can health screening damage your health? f $R$ Coll Gen Pract 1989;39:193-5.

61 Fisher PM, Guinan KH, Burke JJ, Karp WB, Richards JW jr. Impact of a public cholesterol screening program. Arch Intern Med 1990;150:2567-72.

62 Thorell B, Svärdsudd K. Intervention against ischaemic heart disease risk factors in primary health care in a semirural community. The population study " 50 -year-old people in Kungsör”. Scand F Prim Health Care 1994;12:51-6. 
63 Fox GN. Cholesterol: truth in labelling. Fam Pract Res $\mathcal{F}$ 1991;11:241-5.

64 Kinlay S, Heller RF. Effectiveness and hazards of case finding for a high cholesterol concentration. $B M 7$ 1990;300: ing for a

65 Tijmstra T. The psychological and social implications of serum cholesterol screening. International fournal of Risk Safety in Medicine 1990;1:29-44.

66 Rose G, Heller RF, Tunstall Pedoe H, Christie DGS. Heart disease prevention project: a randomised controlled trial in industry. BMF 1989;1:747-51.

67 Feldman W. How serious are the adverse effects of screening? f Gen Intern Med 1990;5 (suppl 5):S50-3.

68 Stewart-Brown S, Farmer A. Screening could seriously damage your health. Decisions to screen must take account of the social and psychological costs. BMf 1997;314:5334 .

69 Roeback JR, Cook JR, Guess HA, Heyse JF. Timedependent variability in repeated measurements of cholesderol levels: clinical implications for risk misclassification and intervention monitoring. f Clin Epidemiol 1993;46: and inter

70 Kent Kwoh C. Cost studies: caveats to the reader. $\mathcal{F}$ Clin Epidemiol 1988;41:211-13.

71 Russell LB, Gold MR, Siegel JE, et al for the Panel on CostEffectiveness in Health and Medicine. The role of cost-effectiveness analysis in health and medicine. $\mathcal{F} A M A$ 1996;276:1172-7

72 Schulman KA, Kinosian B, Jacobson TA, et al. Reducing high blood cholesterol levels with drugs. Cost-effectiveness of pharmacologic management. FAMA 1990;264:3025-33.

73 Lim MCL, Foo WM. Efficacy and cost-effectiveness of simvastatin and gemfibrozil in the treatment of hyperlipidaemia. Ann Acad Med 1992:21:34-7.

74 Blum CB. Comparison of properties of four inhibitors of 3-hydroxy-3-methylglutaryl-coenzyme A reductase lished erratum appears in Am f Cardiol 1994;74:639]. Am $\mathcal{F}$ Cardiol 1994;73:3-11D.

75 Smart AJ, Walters L. Pharmaco-economic assessment of the HMG-CoA reductase inhibitors. $S$ Afr Med 7 1994;84: $834-7$.

76 Schrott HG, Stein EA, Dujovne CA, et al. Enhanced low-density lipoprotein cholesterol reduction and costeffectiveness by low-dose colestipol plus lovastatin combination therapy. Am 7 Cardiol 1995;75:34-9.

77 Oster G, Borok GM, Menzin J, et al. Cholesterol-reduction intervention study (CRIS): a randomized trial to asses effectiveness and costs in clinical practice. Arch Intern Med 1996;156:731-9.

78 Oster G, Borok GM, Menzin J, et al. A randomized trial to assess effectiveness and cost in clinical practice: rationale and design of the Cholesterol Reduction Intervention Study (CRIS). Control Clin Trials 1995;16:3-16.

79 Himmelstein DU, Woolhandler S. Free care, cholestyramine, and health policy. $N$ Engl f Med 1984;311:151114.

80 Weinstein MC, Stason WB. Cost-effectiveness of interventions to prevent or treat coronary heart disease. Ann Rev Public Health 1985;6:41-63.

81 Stason WB. Costs and benefits of risk factor reduction for coronary heart disease: Insights from screening and treatment of serum cholesterol. Am Heart f 1990;119:71824.

82 Oster G, Epstein A. Cost-effectiveness of antihyperlipemic therapy in the prevention of coronary heart disease. The case of cholestyramine. $\mathcal{F} A M A 1987 ; 258: 2381-7$.

83 Kinosian BP, Eisenberg J. Cutting into cholesterol. Costeffective alternatives for treating hypercholesterolemia. fAMA 1988;259:2249-54

84 Martens LL, Rutten FFH, Erkelens DW, et al. Clinical benefits and cot-effectiveness of lowering serum cholesterol levels: The case of simvastatin and cholestyramine in the Netherlands. Am $\mathcal{F}$ Cardiol 1990;65:27-32F.

85 Martens LL, Rutten FH, Erkelens DW, et al. Cost effectiveness of cholesterol-lowering therapy in the Netherlands. Simvastatin versus cholestyramine. Am f Med 1989;87 (suppl 4A):54-8S

86 Sarma S, Fifer SK. Gemfibrozil cost-benefit study. Targeting subgroups for effective hyperlipidaemia drug therapy. Drugs 1990;40 (suppl 1):42-52.

87 Hay JW, Wittels EH, Gotto AM. An economic evaluation of lovastatin for cholesterol lowering and coronary artery disease reduction. Am f Cardiol 1991;67:789-96.

88 Goldman L, Weinstein MC, Goldman PA, et al. Costeffectiveness of HMG-CoA reductase inhibition for primary and secondary prevention of coronary heart disease. FAMA 1991;265:1145-51.

89 Glick H, Heyse JF, Thompson D, et al. A model for evaluating the cost-effectiveness of cholesterol-lowering treatment. Int f Technol Assess Health Care 1992;8:719-34.
90 Hjalte K, Lindgren B, Persson U. Cost-effectiveness of simvastatin versus cholestyramine. Results for Sweden. PharmacoEconomics 1992;1:213-16.

91 Guibert R, Contandriopoulos AP, Champagne F, et al. Cost-effectiveness analysis of lipid modulators in Canada: Results and potential usefulness. Can f Cardiol 1993;9 (suppl):28-9D

92 Goldman L, Goldman PA, Williams LW, et al. Costeffectiveness considerations in the treatment of heterozygous familial hypercholesterolaemia with medications. Am f Cardiol 1993;72:75-9D.

93 Martens LL, Guibert R. Cost-effectiveness analysis of lipidmodifying therapy in Canada: comparison of HMG-CoA reductase inhibitors in the primary prevention of coronary heart disease. Clin Ther 1994;16:1052-62.

94 Hamilton $\mathrm{VH}$, Racicot FE, Zowall $\mathrm{H}$, et al. The costeffectiveness of HMG-coA reductase inhibitors to prevent coronary heart disease. $\mathcal{F A M A}$ 1995;273:1032-8.

95 Pharoah PDP, Hollingworth W. Cost effectiveness of lowering cholesterol concentration with statins in patients with and without pre-existing coronary heart disease: life table method applied to health authority population. BMF 1996; 312:1443-8.

96 Ashraf T, Hay JW, Pitt B, et al. Cost-effectiveness of pravastatin in secondary prevention of coronary artery diesease. Am F Cardiol 1996;78:409-14.

97 Jönsson B, Johannesson M, Kjekshus J, et al, for the Scandinavian Simvastatin Survival Study Group. Costeffectiveness of cholesterol lowering. Results from the Scandinavian Simvastatin Survival Study (4S). Eur Heart 7 1996;17:1001-7.

98 Johannesson $\mathrm{M}$, Jönsson B, Kjeksus J, et al, for the Scandinavian Simvastatin Survival Study Group. Cost effectiveness of simvastatin treatment to lower cholesterol levels in patients with coronary heart disease. $N$ Engl $\mathcal{f}$ Med 1997;336:332-6.

99 Oster G, Epstein AM. Primary prevention and coronary heart disease: The economic benefits of lowering serum cholesterol. Am ₹ Public Health 1986;76:647-56.

100 Wilson MG, Edmunson J, DeJoy DM. Cost effectiveness of work-site cholesterol screening and intervention programs. F Occup Med 1992;34:642-9.

101 Tomson Y, Johannesson $\mathrm{M}$, Åberg $\mathrm{H}$. The costs and effects of two different lipid intervention programmes in primary health care. F Intern Med 1995;237:13-17.

02 McGehee MM, Johnson EQ, Rasmussen HM, et al. Benefits and costs of medical nutrition therapy by registered dietitians for patients with hypercholesterolemia. 95:1041-3.

103 Kelley MD. Hypercholesterolemia: the cost of treatment in perspective. South Med f 1990;83:1421-5.

104 Reckless JPD. The economics of cholesterol lowering. Baillieres Clin Endocrinol Metab 1990;4:947-72.

105 Reckless JPD. Cost-effectiveness of hypolipidaemic drugs. Postgrad Med f 1993;69 (suppl 1):S30-3.

106 Assmann G, Schulte H. Primary prevention of coronary heart disease in the Federal Republic of Germany. Analysis of cost-effectiveness. Drugs 1990;40 (suppl 1):33-7.

107 Kristiansen IS, Eggen AE, Thelle DS. Cost effectiveness of incremental programmes for lowering serum cholesterol concentration: is individual intervention worth while? $B M F$ 1991;302:1119-22.

108 Weissfeld JL, Holloway JJ. Precision of blood cholesterol measurement and high blood cholesterol case-finding and treatment. F Clin Epidemiol 1992;45:971-84.

109 Weissfeld JL, Weissfeld LA, Holloway JJ, et al. A mathematical representation of the Expert Panel's Guide for high blood cholesterol case-finding and treatment. Med Decis Making 1990;10:135-46.

110 Kinlay S, O'Connell D, Evans D, et al. A new method for estimating cost effectiveness of cholesterol reduction therapy for prevention of heart disease. PharmacoEconomics 1994;5:238-48.

111 Field K, Thorogood M, Silagy C, et al. Strategies for reducing coronary risk factors in primary care: which is reducing coronary risk factors in primary care: which is
most cost effective? [see comments]. BMf 1995;310:110912 .

112 Johannesson $M$, Borquist L, Jönsson B, et al, for the CELL Study Group. The cost effectiveness of lipid lowering in Swedish primary health care. F Intern Med 1996;240:23-9.

113 Stinnett AA, Mittleman MA, Weinstein MC, et al. Apendix C: The cost-effectiveness of dietary and pharmacological therapy for cholesterol reduction in adults. In: Gold MR, Siegel JE, Russell LB, et al, eds. Cost-effectiveness in health and medicine. New York: Oxford University Press, 1996: 349-91.

14 Plans Rubio P. Cost-effectiveness of dietary treatment of hypercholesterolemia in Spain. Public Health 1997;111:33- 